\title{
Reforma de sistemas de servicios de salud y equidad en América Latina y el Caribe
}

En los años 80 y 90 América Latina y el Caribe sufrieron enormes transformaciones, cuyo saldo económico y social es desalentador. Las relaciones entre un desarrollo social extremadamente desigual y las dificultades en la implementación de reformas cruciales en las áreas económica y social gozan hoy de consenso en la literatura, en los gobiernos y en los organismos internacionales, lo que ha llevado a revisiones e inclusión del combate a la pobreza como uno de los principales objetivos de las políticas gubernamentales y de la actuación de las agencias multilaterales en la región. La cuestión de la equidad pasó a ser considerada elemento esencial para un desarrollo regional integral y sustentado.

La reforma de los sistemas de servicios de salud está en la agenda de prácticamente todos los programas de los gobiernos de los países latinoamericanos y caribeños. Y esos procesos reformistas están profundamente influenciados por varios fenómenos simultáneos, internos y exógenos, tales como la democratización política del continente, las transformaciones de la economía mundial y las turbulencias concomitantes, las opciones domésticas frente a la globalización, las crisis fiscales del Estado, el aumento de las desigualdades entre los grupos sociales, el apremiante rescate de la enorme deuda social acumulada, la ineficiencia y poca efectividad de las acciones en el sector salud y la inflación de costos en la asistencia médica.

Las opciones políticas que han pautado la reinserción de América Latina en el "nuevo orden mundial", con raras excepciones, no privilegiaron la política social y ha sometido los Estados nacionales a los condicionantes establecidos por los bancos acreedores del endeudamiento regional. El predominio de las ideas neoliberales ha influenciado las agendas de reforma también en el área social y de salud, difundidas como "nuevos paradigmas" de reorganización de los sistemas de servicios, frecuentemente acoplados a los paquetes de ajuste macroeconómico. No obstante, la traducción nacional de esas agendas de cambio es bastante propia y específica de cada país.

Si bien el principio orientador de esas propuestas es la superación de las desigualdades, las evidencias aún no confirman ese resultado, de modo que permanece la necesidad de evaluaciones más refinadas y de metodologías que hagan posible operar políticas orientadas a la equidad en los sistemas de servicios de salud. Por otro lado, los avances poco exitosos conseguidos con la implementación de innovaciones en los sistemas de salud también necesitan ser compartidos y analizados críticamente, posibilitando el intercambio y el aprendizaje entre todos los actores involucrados en esos procesos transformadores. En todo caso, la singularidad de las experiencias nacionales constituye una fuente muy valiosa para la reflexión y el debate.

Este Número Especial de Cadernos de Saúde Pública fue elaborado con la perspectiva de contribuir a ese proceso de discusión, presentando trabajos que procuran captar las trayectorias nacionales vis à vis la dinámica más amplia que ha movido el mundo en estos "tiempos difíciles".

Este trabajo contó con apoyo técnico y operacional de la Red de Investigación en Sistemas y Servicios de Salud en el Cono Sur de América Latina y con ayuda financiera del Centro Internacional de Investigación para el Desarrollo - CIID (International Development Research Center - IDRC) de Canadá. Contribución decisiva también tuvimos del Consejo Editorial de Cadernos deSaúdePública, que aprobó nuestra propuesta. Y no podríamos haber finalizado nuestro trabajo con éxito sin el apoyo fundamental del Editor de Cadernos, Carlos Coimbra, y de su equipo. 


\section{Health systems reform and equity in Latin America and the Caribbean}

Latin America and the Caribbean experienced huge changes in the 1980s and the 1990s, the economic and social balance of which is far from encouraging. The relations between extremely unequal social development and difficulties in the implementation of crucial reforms in the economic and social areas are now a consensus both in the literature, among governments, and in the international agencies, leading to policy revisions and the inclusion of the struggle against poverty as one of the main objectives of government policies and activity by multilateral agencies in the region. The issue of equity is now considered essential for integral and sustained regional development.

Health systems reform has been included on the agenda of virtually all government programs in Latin American and Caribbean countries. Furthermore, these reform processes are deeply and simultaneously influenced by various internal and exogenous phenomena, including political democratization in the region, transformations and concomitant crises in the world economy, domestic options vis-à-vis globalization, the state's fiscal crises, increased inequalities among social groups, the need to redeem the huge accumulated social debt, inefficiency and limited effectiveness of actions in the health sector, and the rising costs of medical care.

With few exceptions, political options that have wagered Latin America's reintegration on "the new world order" have failed to prioritize social policy and have subjected the national states to conditioning factors set by the banks financing the region's debt. Prevailing neoliberal ideas have also influenced the reform agendas in the social field, claimed as "new paradigms" for the reorganization of health systems, frequently coupled to macroeconomic adjustment packages. However, the translation of such agendas for change at the national level is quite specific to each country.

Although the underlying principle of such reform proposals is the attempt to overcome inequalities, evidence to confirm these results is still scarce, and the need persists to enhance evaluations and to establish methodologies allowing for the implementation of policies oriented towards equity in health systems. Both the advances and difficulties in the implementation of innovations in health systems need to be shared and critically analyzed, allowing for exchange and mutual learning among all the stakeholders involved in these transformation processes. In any case, these unique national experiences constitute an interesting source of reflection for the collective debate.

This special issue of Cadernos de Saúde Pública/Reports in Public Health was designed to collaborate in this discussion process, presenting articles which seek to portray the various national experiences vis-à-vis the broader dynamic that has moved the world in these "difficult times".

This task had the technical and operational support of the Network for Research in Health Services and Systems in the Southern Cone of Latin America and the financial support of the International Development Research Center (IDRC) of Canada. We also received decisive support from the Editorial Board of Cadernos deSaúde Pública/Reports in Public Health, which approved the proposal for the special issue. In addition, we could not have concluded our work successfully without the support of the Editor of Cadernos, Carlos Coimbra, and his outstanding staff.

\section{Celia Almeida}

Departamento de Administração e Planejamento em Saúde,

Escola Nacional de Saúde Pública, Fundação Oswaldo Cruz.

Red de Investigación en Sistemas y Servicios de Salud en el Cono Sur. 